\title{
Fatty Cast Measurement
}

National Cancer Institute

\section{Source}

National Cancer Institute. Fatty Cast Measurement. NCI Thesaurus. Code C74766.

The determination of the amount of fatty casts present in a urine sample. 